\section{THE BASUTO.}

SIR GODFREY LAGDEN has given us, in these two volumes under review, a valuable history of the rise of the Basuto nation in the Switzerland of South Africa, under the leadership of a great manMoshesh.

The Basuto, under the sway of this remarkable personage, were for the most part compounded of clans of the so-called Bechuana peoples, yet the root of their present national name-Suto (the $\mathrm{Ba}$ - is merely the plural prefix)--seems to have been derived from the same tribe or district of north-eastern Zululand (Ama-sutu, Usutu) as that which gave rise to the present royal dynasty of the Zulu people, to which Cechwayo belonged. No doubt it sent other enterprising adventurers farther west. By one of these was founded the Ba-suto clan from which Moshesh arose, in the circumstances cited by Sir Godfrey Lagden on p. I9. Moshesh was not directly descended from the stock of some bygone Zulu adventurer, whose tribal name-Suto or Sutu-had been adopted by these Bechuana people, but from a distant relative of the same racial origin whose ancestors had remained in the Amahlubi country to the south. The grandfather of Moshesh, however, had been adopted as a son and successor by Sekake, a Bakwena chief (apparently descended on one side from the original Umu-sutu). This adopted son was called Pete. He was succeeded by his own son, Mokachane, who was the father of Moshesh (this name as it stands mears "a woman's garment" in the Se-suto language, but Sir Godfrey states that it is more probably an abbreviation of "Mosheshwe," which he interprets as "shaver" or "leveller"). The birth of Moshesh must have taken place about I792, at Monkhoaneng, in Northern Basutoland.

About $1_{1} 1_{5}$, Chaka obtained complete control over the Zulu Kafirs of Zululand and Eastern Natal, and commenced that series of bloodv wars in which, at the lowest possible estimate, a million Bantu negroes perished: wars which started a series of convulsions amongst the negroes of South Africa, that only came to an end by the death of Lobengula in I894, the capture of Gungunyane by the Portuguese in 1895 , and the complete subjugation (by force and by diplomacy) of the Angoni Zulus of Western Nyasaland by Sir Alfred Sharpe in 1906.

Wave after wave of Kafir or Zulu invasion of Basutoland took place after 1820 , and, but for the mountainous character of Basutoland and the valour and genius for warfare of the Boers, not even Moshesh could have saved the remnant of the southern Bechuana peoples who gathered round him. But he found in Thaba Bosigo-the "Mountain of Night," under the shadow of Mount Machache, in northwestern Basutoland-a stronghold from which no force-black or white-ever availed to dislodge him. The Zulu conqueror, Moselekatsi, might, perhaps, have succeeded (in spite of one severe repulse) in

1 "The Basutos; the Mountaineers and their Country." By Sir Godfrey Lagden, K.C.M.G. 2 vols. Vol. i., pp. $x v i+338$; vol. ii., pp. $x i i+339-690$. (London: Hutchinson and Co., Igog.) Price 24 s. net.

NO. 2 III, VOL. 83] taking Thaba Bosigo and establishing a secondary Zulu power in Basutoland (about 1832 ), but he could only have done this by surrounding the mountain and gradually starving out the Basuto clan. This purpose, even if he entertained it, was thwarted by the action of the emigrant Boers, who, by means of their firearms and system of laager camps (a defence of linked wagons), defeated Moselekatsi and drove him permanently beyond the Limpopo River.

Thus it was mainly the action of the white man which enabled the Basuto clan of the Southern Bechtana to expand into the Basuto nation. The emigrant Boers, after soundly thrashing Moselekatsi, saved from complete extermination the Bechuana peoples

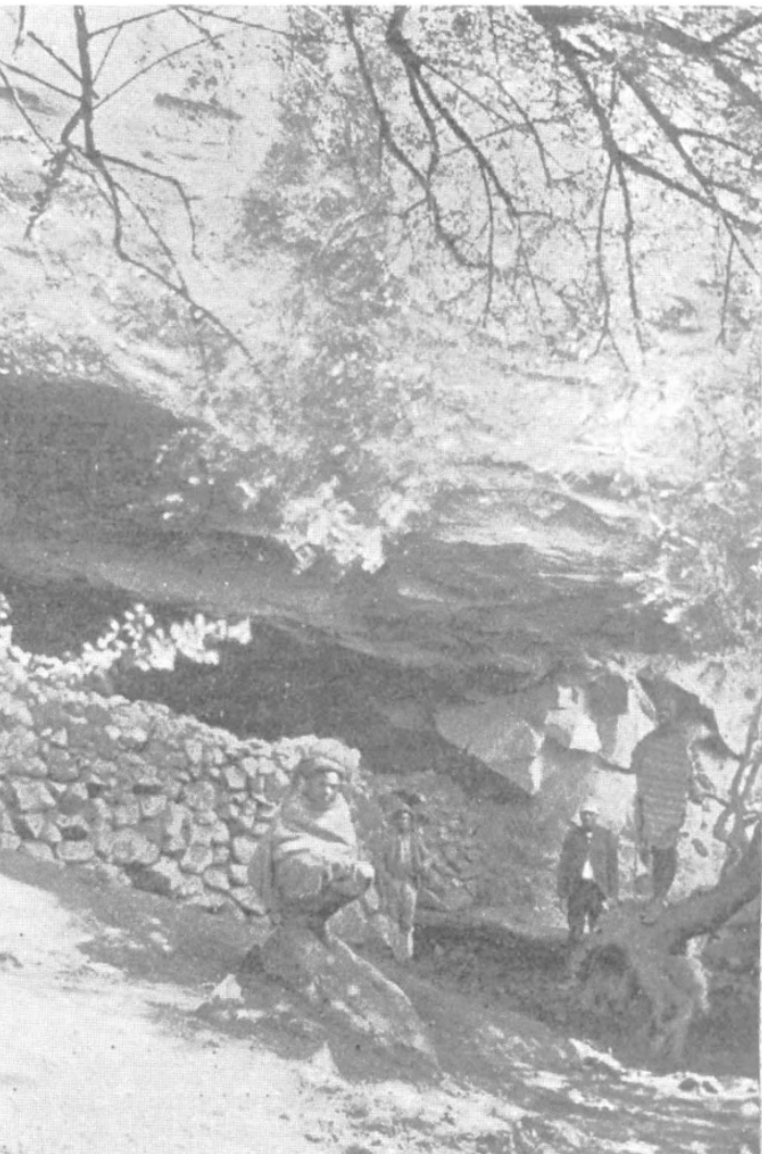

Photo. by T. Lindsay Faurclough]

IG. I. - Fortified Cave at Lebise Masupha's Berea. From "The Basutos."

between the Kalahari Desert and Lake N'gami on the north and the Drakensberg Mountains on the south. The emigrant farmers themselves occupied, in the first instance, the less mountainous elevated plateaus to the north of the Caledon River.

But although Moshesh and his Basuto received the first missionaries (I833) gladly, and practically at no time put any opposition in the way of the spread of Christianity and education, they strongly objected to the Boers as settlers in what is now the Orange Free State. They wished to learn the wisdom of the white man, and, above all, to acquire his firearms and his horses (early in the igth century they had begun that affection for the horse which has resulted in the re- 
marlsable breed of Basuto ponies and the creation of a Basuto cavalry that has been, and will be, no negligible quantity in the forces of South Africa). Moshesh and his descendants, as soon as they saw a chance, entered into friendly relations with Moselekatsi in the far north, and his son Lobengula, with the kings of Zululand, and the more powerful clans of British Kaffraria and Northern Natal. In fact, no sooner were they relieved from the menace of Zulu conquest by the action of the Boers than they strove by many subtle means to push the white man as far away as possible from the centre of South Africa.

Their dislike of the British was quite as great as their dislike of the Boers. Between 1840 and $185^{2}$

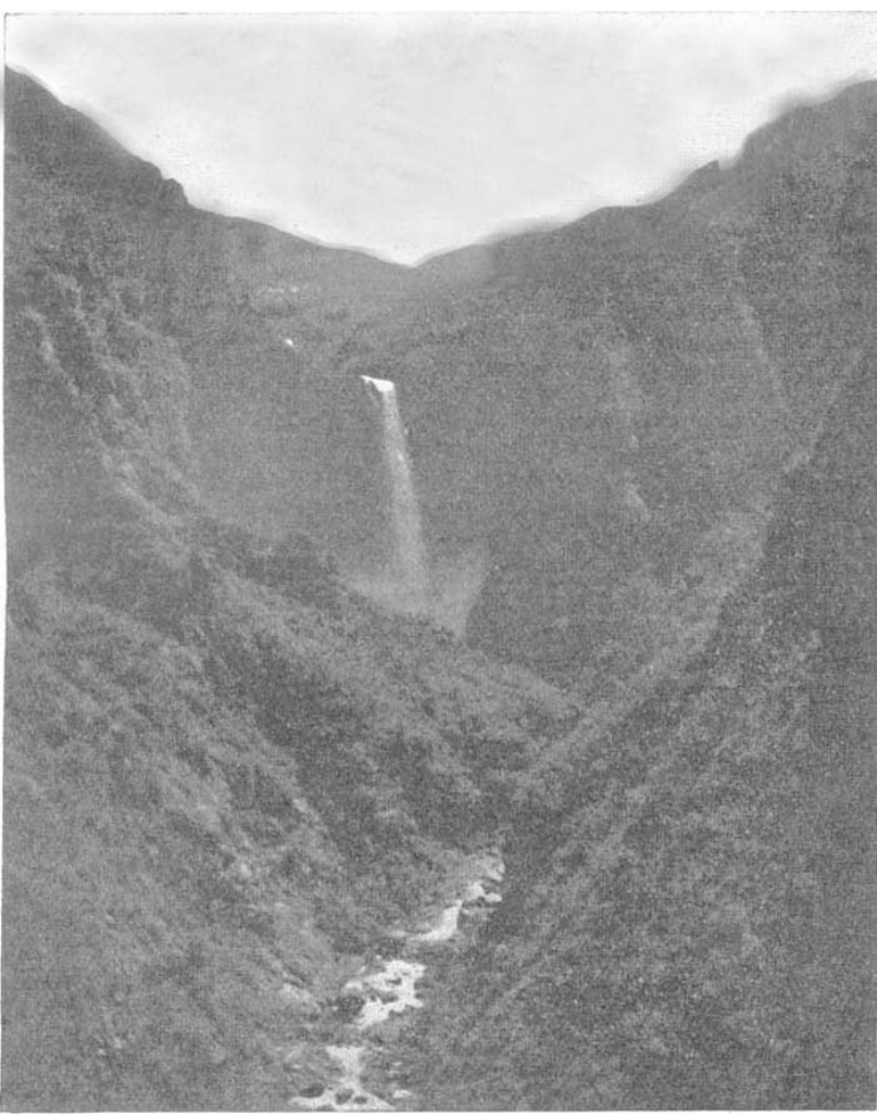

FIG. 2.-Ketane Falls and Gorge. From "The Basutos."

Moshesh and his chiefs made use of the British power to stave off a Boer conquest of their country. After that they attempted an aggressive attitude towards even the British, and inflicted on the soldiers of Sir George Cathcart a very serious repulse. From 1858 onwards they fought intermittently with the Orance State Boers (the Basuto being the aggressors), until at last, getting worn out in the struggle with these dogged white men, they invoked British protection in i868. They were annexed as a Native State to the government of Cape Colony in 1872 , but an attempt to disarm them brought on a fresh outbreak of warfare, in which the Cape forces gained no laurels and General Gordon's intervention proved futile. In 1884 Basutoland was disannexed, and has henceforth been directly controlled by the Imperial Government.
Since 1884 , when the native negro population of this State (which is nearly the size of Belgium) amounted to about I70,000, the total number of the Basuto has risen to nearly 400,000 at the close of 1909. Education, under French Protestant and British Wesleyan missionaries, has made considerable strides. The country, in fact, is so prosperous that it is becoming a factor of increasing importance in the problem of South Africa. Basutoland (the reviewer thinks) should have been made-if the advice of the one or two statesmen-governors of South Africa had been listened to in the first half of the Igth century-the Empire State of South Africa, the principal stronghold in all that region of the white race; and ample territories farther north or farther south might have been allotted then to the few thousand Basuto, who asked for little more at that period than peace, security, and an inalienable right to a reasonable amount of land. Now, as things are constituted, Basutoland is emphatically a black man's country, ${ }^{1}$ and from Basutoland radiates a vigorous impulse which will go far towards securing for the black man eventual terms of equal partnership with the white in the administration of the southern half of Africa. Lest we should be petty-minded and regret this, let us turn our eyes to the recently explored regions of Northern Rhodesia, portions of Nyasaland and Katanga (greatly denuded of indigenous populations by various causes) which now invite settlement, almost by the million, on the part of adventurous white peoples.

The volumes reviewed deal mainly with the history of this interesting Basuto people. They are well illustrated by good photographs, and the numerous pictures of the Basuto types show clearly the three neyro elements, imperfectly fused, from which this section of the Bechuana peoples has been built up. There is that of the Bushman (who immediately preceded the Basuto as the indigenous occupant), of the ugly flat-nosed type of Forest Negro or Pigmy (which reappears elsewhere in South Africa), and finally the typical Bantu strain from East Central Africa which imparts to many of the Basuto faces refinement of outline and considerable brain capacity. The scenery of Basutoland (the reviewer writes from actual experience) is amongst the grandest of the world's landscapes, and Sir Godfrey Lagden has taken care to emphasise this by "Wort und Bild." The second volume closes with serviceable notes on the Suto dialect and appendices of great usefulness to the student of Africa. The book is, however, of very great general interest. H. H. JoHnston.

\section{THE OCEANOGRAPHICAL MUSEUM AT} MONACO.

$A \mathrm{~S}$ stated in last week's NaTure, the inauguration of the Oceanographical Museum at Monaco took place on March 28, in the presence of representatives of the Governments and navies of France, Germany, Italy, Spain, and Portugal, and a great gathering of men of science of all nations, who were invited by the Prince of Monaco, and entertained as his guests in his ancient palace at Monaco and in various hotels in Monte Carlo. The inaugural fêtes lasted for four 1 Note Sir Godfrey's remarks on this, p. 645 , vol. ii.

NO. 2 III, VOL. 83] 